\title{
МІЖНАРОДНА КОНЦЕПЦІЯ ПОЛІКУЛЬТУРНОГО ВИХОВАННЯ
}

Погребняк В. А. Міжнародна концепція полікультурного виховання.

У статті здійснено педагогічний аналіз міжнародної концепції полікультурного виховання. Розкрито перспективи реалізації полікультурного підходу у вітчизняній освітній системі в контексті інтеграції України до світового і європейського співтовариства.

Ключові слова: полікультурне виховання, полікультурне виховне середовище, міжнародна концепція полікультурного виховання, полікультурна компетентність.

Погребняк В. А. Международная концепция поликультурного воспитания.

В статье осуществлен педагогический анализ международной концепции поликультурного воспитания. Раскрыты перспективы реализации поликультурного подхода в отечественной образовательной системе в контексте интеграции Украины в мировое и европейское содружество.

Ключевые слова: поликультурное воспитание, поликультурная воспитательная среда, международная концепция поликультурного воспитания, поликультурная компетентность.

Pogrebnyak V. A. International conception of multicultural education.

The pedagogical analysis of international conception of multicultural education is carried out. The prospects of multicultural approach embodiment into the native educational system in the context of integration of Ukraine to the world and European community are exposed.

Key words: multicultural education, multicultural educational environment, international conception of multicultural education, multicultural competence.

Значне посилення інтеграційних і глобалізаційних процесів, які забезпечують взаємний обмін, взаємозбагачення й тісне співробітництво країн і народів практично в усіх сферах життя в загальносвітовому масштабі, нині потребує відповідних змін освітньої галузі України в напрямі реалізації принципу полікультурності, підготовки молоді до повноцінної життєдіяльності в умовах широкої міжнародної взаємодії, засвоєння знань і формування практичних умінь і навичок плідної праці в інтернаціональному контексті.

У зв’язку з цим проблеми забезпечення інтернаціоналізації освіти й полікультурного виховання молодого покоління все частіше стають предметом наукових досліджень у галузі педагогіки, психології, філософії освіти. Зокрема, філософські й методологотеоретичні основи полікультурності як соціокультурного феномену розкривають Н. Авшенюк, Дж. Бенкс, Дж. Гартлі, О. Джуринський, С. Драгоєвич, I. Зязюн, Д. Кемпбелл, М. Лещенко, В. Макаєв, 3. Малькова, Л. Супрунова, А. Сбруєва, О. Сухомлинська, Г. Хоув та інші. дослідники. Теоретико-методичні проблеми здійснення навчально-виховного процесу в системі середньої та вищої освіти на засадах полікультурності у вітчизняному й зарубіжному педагогічному досвіді розробляються в наукових працях Дж. Аббат-Вона, Е. Ананьян, В Бойченко, П. Брандера, Дж. Гебріел, Г. Деї, О. Моляко, Р. Раджабової, А. Солодкої, Т. Устименко, Дж. Хайварда, А. Чирви та ін. Проте бібліометричний аналіз наявних вітчизняних науково-педагогічних джерел засвідчує відсутність цілісних досліджень міжнародної освітньої політики в галузі полікультурного виховання, що, на наш погляд, уповільнює розроблення теоретичних основ і нормативно-правової бази системи освіти в Україні в питаннях полікультурної підготовки молоді. Тому, зважаючи на важливість проблеми i ii недостатню розробленість, метою статті обрано педагогічний аналіз міжнародної освітньої політики у галузі полікультурного виховання для подальшого визначення пріоритетних напрямів реформування вітчизняної освіти відповідно до магістральних тенденцій розвитку цієї сфери в загальносвітовому масштабі. 
Незважаючи на те, що полікультурність як освітній, виховний i соціокультурний феномен відомий i, відповідно, представлений у наукових дослідженнях фактично від першої чверті минулого століття [3, с. $62 ; 13$, с. 25; 14], до європейської політичної й академічної лексики мультикультуралізм увійшов тільки з середини 1980-х років, однак ще не ставши втіленням офіційної державної освітньої політики $[11 ; 12]$. Проте, вже від середини XX століття зростаючу увагу світового співтовариства до питань додержання прав людини, боротьби 3 соціальною, культурною i расовою дискримінацією підтверджують такі ключові документи Генеральної Асамблеї ООН, як Загальна декларація прав людини (1948), Деклараџія прав дитини (1959) і Конвенція про права дитини (1989) (табл. 1) [7, с. 7, 9, 13].

Таблиия 1

Рішення Генеральної Асамблеї ООН щодо виховання в полікультурному середовищі

\begin{tabular}{|c|c|c|}
\hline Рік & Документ & Витяги \\
\hline $48^{19}$ & $\begin{array}{l}\text { Загальна } \\
\text { декларація } \\
\text { людини }\end{array}$ & $\begin{array}{l}\text { Стаття 26. «Освіта має сприяти взаєморозумінню, } \\
\text { терпимості ц̌ дружбі між усіма народами, расовими чи } \\
\text { релігійними групами ...» }\end{array}$ \\
\hline 19 & $\begin{array}{l}\text { Декларація п] } \\
\text { дитини }\end{array}$ & $\begin{array}{l}\text { Принцип 10. «Дитина має бути захищена від практики, яка } \\
\text { може заохочувати расову, релігійну або будь-яку іншу форму } \\
\text { дискримінації. Вона повинна виховуватися в дусі } \\
\text { взаєморозуміння, терпимості, дружби між народами, миру } i \\
\text { загального братерства...» }\end{array}$ \\
\hline $89^{19}$ & $\begin{array}{rr}\text { Конвенція } & \text { п1 } \\
\text { права дитини } & \end{array}$ & $\begin{array}{l}\text { Стаття 29. «.. освіта дитини має бути спрямована на: (...) } \\
\text { с) виховання поваги до ... культурної самобутності, мови та } \\
\text { національних иінностей краӥни, в якій дитина проживає, до } \\
\text { крайни ї̈ походження та цивілізацій, відмінних від ї̈ власної; } \\
\text { d) підготовку дитини до свідомого життя у вільному } \\
\text { суспільстві в дусі розуміння, миру, терпимості, рівноправності } \\
\text { чоловіків і жінок та дружби між усіма народами, етнічними, } \\
\text { національними і релігійними групами, а також особами з } \\
\text { корінного населення» }\end{array}$ \\
\hline
\end{tabular}

Починаючи з 1960-х років, Радою Свропи також прийнято цілу низку офіційних документів, які безпосередньо торкаються питань виховання особистості в полікультурному середовищі (табл. 2) $[2 ; 10$, c. $120 ; 11$, c. $104-113]$.

Таблиия 2

Рішення Ради Європи у галузі полікультурного виховання

\begin{tabular}{|c|c|c|}
\hline Рік & Документ & Витяги \\
\hline 1961 & $\begin{array}{l}\text { Рекомендація 285 } \\
\text { Свропи } \\
\text { національних меншин }\end{array}$ & $\begin{array}{l}\text { «особам, які належсать до національної меншини, не може бути } \\
\text { відмовлено в праві ... користуватися своєю культурою і мовою, } \\
\text { відкривати свої школи й обирати за бажанням мову навчання» }\end{array}$ \\
\hline 1975 & $\begin{array}{l}\text { Резолюція } 13 \text { Кабінету } \\
\text { міністрів Ради Свропи }\end{array}$ & $\begin{array}{l}\text { «рекомендує ... заходи, спрямовані на ... збереження культурноі } \\
\text { спадщини і самобутності» }\end{array}$ \\
\hline 1976 & $\begin{array}{ll}\text { Рекомендація } & \text { Ради } \\
\text { міністрів освіти } & \text { Ради } \\
\text { Європи } & \\
\end{array}$ & $\begin{array}{l}\text { «слід докладати зусиль для того, щоб за сприяння батьківщини } \\
\text { іммігрантів навчати їхніх дітей рідною мовою» }\end{array}$ \\
\hline 1977 & Директива Ради Свропи & $\begin{array}{l}\text { «.. ужживати заходів, щоб за сприяння краӥни походження } \\
\text { навчати дітей іммігрантів їхній рідній мові } і \text { культурі» }\end{array}$ \\
\hline 1981 & $\begin{array}{l}\text { Рекомендація } 928 \text { Ради } \\
\text { Європи }\end{array}$ & $\begin{array}{l}\text { «рекомендуе поступовий перехід до навчання дітей ӥхньою } \\
\text { рідною мовою» }\end{array}$ \\
\hline 1983 & $\begin{array}{ll}\text { Резолюція } & \text { Свро- } \\
\text { парламенту } & \end{array}$ & «закликає вжити заходів із захисту мов меншин» \\
\hline 1984 & $\begin{array}{l}\text { Рекомендація R (84) Ради } \\
\text { Свропи }\end{array}$ & $\begin{array}{l}\text { «... зробити міжккультурний аспект частиною підготовки } \\
\text { вчителів і підготовки без відриву від роботи» }\end{array}$ \\
\hline 1985 & $\begin{array}{l}\text { Рекомендація R (85) Ради } \\
\text { Свропи }\end{array}$ & $\begin{array}{l}\text { «... сприяти викладанню і вивченню прав людини ... у шкільній } \\
\text { програмі, що включає міжскультурне розуміння» }\end{array}$ \\
\hline
\end{tabular}




\begin{tabular}{|c|c|c|}
\hline 1988 & $\begin{array}{lr}\text { Резолюція } 192 \text { Постійної } \\
\text { конференції місцевих і } \\
\text { регіональних } \\
\text { Свропи }\end{array}$ & $\begin{array}{l}\text { «... укласти угоди щцодо заходів, які сприяють } \\
\text { використовуванню регіональної мови ...» }\end{array}$ \\
\hline 1992 & $\begin{array}{l}\text { Свропейська хартія } \\
\text { регіональних мов або мов } \\
\text { меншин (ETS } 148 \text { re) }\end{array}$ & $\begin{array}{l}\text { «... охорона } i \text { розвиток регіональних мов або мов мениин у } \\
\text { різних країнах та регіонах Свропи є важливим внеском у } \\
\text { розбудову Свропи, щзо трунтується на принципах демократії та } \\
\text { культурного розмаїття ...» }\end{array}$ \\
\hline 1995 & $\begin{array}{l}\text { Рамкова } \\
\text { про захист } \text { національних } \\
\text { меншин (ETS 157) }\end{array}$ & $\begin{array}{l}\text { «... плюралістичне та справді демократичне } \\
\text { суспільство має не тільки поважати етнічну, культурну, мовну } \\
\text { та релігійну самобутність кожної особи, ... але й створювати } \\
\text { відповідні умови для виявлення, збереження та розвитку иієї } \\
\text { самобутності ...» }\end{array}$ \\
\hline
\end{tabular}

Як бачимо з наведених витягів, зміст рекомендацій і директив поступово еволюиіонує від простої констатації відсутності заборон і правових обмежень щзодо національних, етнічних $i$ культурних груп до більш дієвого сприяння розвиткові багатокультурного суспільства.

Віденським самітом 1993 року в структурі Ради Європи започатковано нову інституцію - Європейську Комісію проти расизму й дискримінащії, якою відтоді в якості керівних положень для країн - членів СС затверджено цілий ряд рекомендацій щодо предмета їі діяльності (табл. 3) [11, с. 10-12].

Таблиия 3

Рекомендації Європейської Комісії проти расизму й дискримінації

\begin{tabular}{|c|c|}
\hline 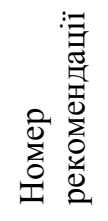 & Зміст \\
\hline 1. & $\begin{array}{l}\text { Містить загальні директиви й рекомендації для національних урядів, стурбованих } \\
\text { законними політичними аспектами боротьби з расизмом і нетерпимістю. }\end{array}$ \\
\hline 2. & $\begin{array}{l}\text { Розглядаються можливі національні інституції для боротьби } 3 \text { расизмом, } \\
\text { ксенофобією, антисемітизмом і дискримінацією. Додатки вміщують пропозиції щодо } \\
\text { принципів, структури й організаційних форм, а також функцій і повноважень таких } \\
\text { iнституцій. }\end{array}$ \\
\hline 3. & $\begin{array}{l}\text { Стосується подолання расової дискримінації циган. Пропонуються конкретні заходи } \\
\text { для забезпечення їхніх соціальних і культурних прав. }\end{array}$ \\
\hline 4. & $\begin{array}{l}\text { Аналізуються шляхи інформування громадськості про наявні випадки расизму й } \\
\text { нетерпимості для відповідного формування суспільної свідомості. }\end{array}$ \\
\hline 5. & $\begin{array}{l}\text { Виявляється суспільна упередженість у ставленні до мусульман. Окреслюються } \\
\text { напрями боротьби з дискримінаційними виявами на релігійному грунті. }\end{array}$ \\
\hline 6. & $\begin{array}{l}\text { Розглядається проблема розповсюдження расистської ідеології через Інтернет. } \\
\text { Урядам пропонується вживати заходів на національному й міжнародному рівнях для } \\
\text { ефективної протидії використанню сучасних засобів комунікації } 3 \text { расистською, } \\
\text { дискримінаційною чи антисемітською метою. }\end{array}$ \\
\hline 7. & $\begin{array}{l}\text { Представлені рекомендації щодо законодавчих ініціатив у боротьбі з расизмом, які } \\
\text { охоплюють конституційне, кримінальне, цивільне й адміністративне право, стосуються } \\
\text { не тільки прямої, але й прихованої дискримінації, включаючи расові висловлювання й } \\
\text { обра́зи. }\end{array}$ \\
\hline 8. & $\begin{array}{l}\text { Увага зосереджується на положенні, що боротьба } 3 \text { тероризмом не звільняє від } \\
\text { необхідності дотримання прав людини. }\end{array}$ \\
\hline 9. & Присвячується різним аспектам боротьби з антисемітизмом. \\
\hline
\end{tabular}

Стосовно фундаментальних засад діяльності сучасної європейської вищої школи зазначимо, що 
теоретичне обгрунтування ролі принципу полікультурності як одного 3 визначальних здійснено майже в усіх нормативних документах Болонського процесу. Зокрема, у Сорбоннській декларащиї (25 травня 1998 року, Париж) започатковано створення Європейського простору вищої освіти, «де національні особливості і спільні інтереси можуть взаємодіяти й посилювати один одного задля вигоди Європи, іiї студентів та, в загальному сенсі, iii громадян» [8, с. 135]. I, нарешті, основний документ - Болонська конвенція (18-19 червня 1999 року, Болонья) - також утверджує необхідність утворення зони європейської вищої освіти «з дотриманням повної поваги до різноманітних культур, мов, національних систем освіти ...» [4, с. 138]. У комюніке Конференції міністрів вищої освіти (19-20 вересня 2003 року, Берлін) зазначається, що метою створення загальноєвропейського простору вищої освіти є «збереження європейського культурного багатства і мовної різноманітності, які грунтуються на культурній спадщині різних традицій та стимулюванні інноваційного потенціалу і соціального та економічного розвитку за допомогою розширеного співробітництва ...» [9, с. 147]. Наведені факти, вважаємо, достатньо яскраво підтверджують, що освітня галузь прагне відповідати сучасності й забезпечувати вимоги полікультурного суспільного середовища, водночас зберігаючи, збагачуючи й розвиваючи культурне різноманіття в умовах єдиного багатокультурного соціуму.

Отже, проведене науково-педагогічне дослідження дозволяє дійти таких висновків. Питання впливу полікультурного простору на процеси виховання й навчання молодого покоління зацікавлюють науковців зарубіжжя, починаючи з першої чверті XX століття. Розуміння мультикультуралізму й підходи до теорії полікультурного виховання особливо поширюються й поглиблюються від середини минулого сторіччя найперше завдяки активізації міграції та боротьби соціокультурних меншин за власні права. У такій ситуації західні філософи, культурологи й педагоги вбачають у полікультурному вихованні шлях до виходу з сучасної кризи міжкультурних взаємин. У зв'язку з цим полікультурне виховання в зарубіжних країнах розвивається як перспективний педагогічний напрям зміни смислового наповнення, змісту й методів підготовки молоді до життєдіяльності в багатокультурному середовищі, внаслідок чого полікультурність перетворюється на провідний педагогічний принщип. Спираючись на нього, сучасна зарубіжна педагогічна теорія й практика прагне відображувати різноманітність і рухливість соціокультурного середовища, зосереджуючи увагу на міжкультурному порозумінні та подоланні культурного відчуження.

Здійснений педагогічний аналіз вітчизняної теорії i практики полікультурного виховання [6] дозволяє зробити висновок про стратегічний розвиток цієї галузі відповідно до провідних світових тенденцій. Більшість українських дослідників проблеми визнає полікультурність провідним принципом і кардинальною стратегією розвитку новітньої світової освітньої системи. Зазначається взаємозумовленість уселюдського i національного компонентів у вихованні полікультурної свідомості громадянина демократичної держави, стверджується, що формування поваги до культурної автентичності й адекватного сприйняття відмінностей інших починається з усвідомлення власної культурної ідентичності й через національну культуру народу [6, с. 82-89]. Спираючись на офіційні державні освітні документи (Концепція громадянського виховання особистості в умовах розвитку української державності, Національна доктрина розвитку освіти України у XXI столітті й інші), зарубіжний педагогічний досвід, а також наукові пошуки вітчизняних дослідників, можемо сформулювати такі основні завдання полікультурного виховання в Україні:

- засвоєння знань про власну культурну спадщину в загальносвітовому цивілізаційному контексті, формування уявлень про культурну різноманітність і рівноправність (культурна ідентифікація);

- забезпечення позитивного ставлення до культурних відмінностей через виховання полікультурної свідомості (полікультурна мотивація);

- розвиток практичних умінь взаємодії у полікультурному просторі на засадах 
порозуміння та демократії (полікультурна компетентність).

Недоліки в сучасній вітчизняній практиці підготовки молоді до життя в полікультурному просторі полягають у притаманних українській освітній системі явищах етноцентризму у змістовому наповненні й смисловому навантаженні навчальних дисциплін і в загальній спрямованості виховної роботи [1, с. 44; 6, с. 81-82]. У зв'язку з цим нерозв'язаною залишається проблема поліцентричного висвітлення культурної різноманітності у вітчизняних підручниках, посібниках та інших складниках методичного супроводу навчально-виховного процесу. Одним із безкомпромісних аспектів удосконалення полікультурного виховання у вітчизняній освітній системі, який ще очікує на практичне втілення, $є$ забезпечення відповідної підготовки педагогічних кадрів, формування професійної педагогічної полікультурної компетентності вчителя [5].

Уходження України до світового та європейського співтовариства, орієнтація вітчизняної освітньої системи на положення Болонського процесу вимагають усунення вказаних прогалин. У зв'язку з цим актуалізується потреба вивчення зарубіжного досвіду полікультурного виховання й підготовки педагога до його здійснення. Одним із перспективних напрямів наукового пошуку $\epsilon$ дослідження підготовки майбутнього вчителя до професійної діяльності в умовах полікультурного середовища в системах педагогічної освіти зарубіжних країн.

\section{Література}

1. Багатокультурність i освіта. Перспективи запровадження засад полікультурності в системі середньої освіти України: аналітичний огляд та рекомендації / за ред. О. Гриценка. - К. : УЦКД, 2001. - 58 с. 2. Бюро інформації Ради Європи в Україні [Електронний ресурс] // http: //www. coe. kiev. ua / docs / ets. - 30 жовтня 2012 року. 3. Винниченко В. Щоденник / [редакція, вступна стаття і примітки Г. Костюка] / В. Винниченко. - Едмонтон; Нью-Йорк, 1980. - 590 с. 4. Зона європейської вищої освіти // Вища освіта України і Болонський процес : [навч. посіб.] / [за ред. В. Г. Кременя; авт. кол. : М. Ф. Степко, Я. Я. Болюбаш, В. Д. Шинкарук та ін.]. - К. : Освіта, 2004. - С. 138. 5. Погребняк В. А. Полікультурна підготовка майбутнього вчителя у педагогічному процесі вищої школи / В. А. Погребняк // Професіоналізм педагога в контексті Свропейського вибору України : міжнар. наук.-практ. конф., 18- 20 вересня 2008 р. : [зб. статей]. - Ялта : РВВ КГУ, 2008. - Ч. 5. - С. 97-101. 6. Погребняк В. Актуальні проблеми розвитку вітчизняної теорії полікультурного виховання / В. Погребняк // Зб. наук. праць Полтавського держ. пед. ун-ту ім. В. Г. Короленка. - Вип. 7 (46). Серія «Педагогічні науки». - Полтава, 2005. - С. 80-90. 7. Права дитини : витяги з міжнародних документів. - Полтава : Гротеск, 1998. - 15 с. 8. Спільна декларація про гармонізацію архітектури європейської системи вищої освіти // Вища освіта України і Болонський процес : [навч. посіб.] / [за ред. В. Г. Кременя; авт. кол. : М. Ф. Степко, Я. Я. Болюбаш, В. Д. Шинкарук та ін.]. - К. : Освіта, 2004. - С. 135. 9. Створення загальноєвропейського простору вищої освіти // Вища освіта України і Болонський процес : [навч. посіб.] / [за ред. В. Г. Кременя; авт. кол.: М. Ф. Степко, Я. Я. Болюбаш, В. Д. Шинкарук та ін.]. - К. : Освіта, 2004. - С. 147. 10. Тарроу Н. Язык, межкультурализм и права человека / Н. Тарроу // Перспективы. - 1993. - № 4. - С. 107-132. 11. Activities of Council of Europe with Relevance to Combating Racism \& Intolerance. -Strasbourg : European Commission Against Racism \& Intolerance. -CRI (2004) 7. - 113 p. 12. Boehringer M. Learning to Walk in Each Other's Shoes : Intercultural Training and the Business-German Classroom / M. Boehringer / [Kluth Cothran B., A. K. Gramberg (Eds.)] // The Global Connections : Issues in Business German. -Waldsteinberg : Heidrun Popp., 2002. - P. 101-125. 13. Dewey J. Democracy and Education. An Introduction to the Philosophy of Education / J. Dewey. - N.- Y. : The Free Press, 1916.-378 p. 14. Kallen H. Culture and Democracy in the United States / H. Kallen. - N.-Y., 1924.-123 p. 